\title{
A study to assess the effectiveness of structure teaching programme on knowledge regarding zika fever and its management among patients admitted in medical ward in District Hospital
}

\author{
M.Raghavendran ${ }^{1}$ \\ ${ }^{1}$ Asso. Prof., Rama College of Nursing, Rama University, \\ Kanpur, UP., India
}

\begin{abstract}
A pre experimental study was conducted with the objectives to assess the knowledge regarding Zika fever and its management among medical patients admitted in ward. To assess the effectiveness of structure teaching programme on knowledge regarding zika fever and its management and prevention.To associate between post-test knowledge level with demographic variables of Medical ward patients. A Quantitative research approach with the sample size of 60 patients those who are admitted in medical ward were selected by convenient Non-probability sampling technique. The study was Pre experimental research with one group pre- test post- test design, the structure questionnaire as a tool for data collection. The overall major finding of the study reveal that In pre-test out of 60 samples 40 were inadequate knowledge, 20 having moderately adequate knowledge and none of them have adequate knowledge but in post-test 12 having Inadequate knowledge, 42 having moderately adequate knowledge and 6 of them having adequate knowledge. The mean and standard deviation value of knowledge were in pre-test Mean was 8.37, standard deviation was 2.04 and in post-test Mean was 12.7 , standard deviation was 2.14 . In the present study it was found that the effectiveness of structure teaching programme on zika fever was assessed by paired t test. The value of $t$ is 10.4 at the level of $t$ $=0.05$ level which is higher than the table value $\mathrm{t}=$ 2.05 which show highly Significance.
\end{abstract}

Key words: effectiveness, knowledge, zika fever, management

\section{INTRODUCTION}

Health is a state of well-being of an individual. It is said that to be healthy, individual should be free from disease. Disease is the major aspect to make an individual unhealthy. In the field of science, diseases are mainly classified into two major groups they are communicable disease and non- communicable disease. Most of the communicable diseases are infectious hence they can be called as infectious disease.

Communicable diseases are diseases that are as a result of the causative organism spreading from one person to another or from animals to people. They are transmitted by direct contact [with body excreta or discharge from an ulcer, open sore or respiratory tract] or by indirect contact with animate objects such as flies, mosquitoes or other insect capable of spreading the disease.

World- wide infectious diseases are the leading cause of death of children and also in adult, sixteen percentage of all death in each year are due to infectious disease. Since many infectious diseases are treated and cured. Many diseases are upcoming day by day. The new variety of disease is infecting humans one of them at present is zika fever.

Zika fever is a mosquito-borne flavi-virus disease transmitted by Aedes mosquito that was first identified in Uganda at 1947 in monkey's through a network that monitored yellow fever. It was later identified in human in 1952 in Uganda and United Republic of Tanzania, outbreak of zika virus disease have been recorded in Africa, the area and the 
specific. It was subsequently isolated from a human in Nigeria in 1954.

\section{NEED FOR THE STUDY}

The World Health Organization has declared that rapid spread of zika virus a public health emergency, one that is exacerbated by a lack of information about how the virus affected the human body. Unlocking these unknowns of develop treatment, prevent infections and slow zika's spread requires global collaboration. Although many studies are carried out about the cause, treatment, complications but still the problem persists. Some patients are there who do not have knowledge regarding the disease which lead to the development of complication and even death. No cases reported in India and to reduce the case of zika fever and promote their health. It is important to prevention involves the decreasing mosquitoes bites in area for the use of insect repellent covering much of the baby with clothing, mosquito nets and getting rid of standing water where mosquitoes reproduce.

People infected with zika can pass on the virus to other through sexual intercourse. As it has been documented in at least 4 cases with several more under investigation by the CDC.

The prevalence of zika virus infection in Uganda 6.1 in 1952 among a population of 99 residents. It $7.1 \%$ in Indonesia from 1977-1978 among patient who were hospitalization for fever. The Brazil ministry of health estimated around 440,000 - 1,300,000 suspected cases of zika fever infection in December 2015. In March 2016, WHO reported that 12 of which have reported an increase in Guillain- barre syndrome cases of zika virus among patient.

\section{OBJECTIVES:}

- To assess the knowledge regarding zika fever and its management among patients admitted in medical ward.

- To assess the effectiveness of structure teaching programme on knowledge regarding zika fever and its management and prevention.

- To associate the post-test knowledge level with demographic variables of patients admitted in medical wards.

\section{HYPOTHESIS :-}

H1:- There is a significant increase in the knowledge of patients after attending STP.

H2:- There is a significant association of pre-test knowledge score with selected demographic variables of patients.

\section{METHODOLOGY}

\section{Research Approach}

The research approach for the study was Quantitative Approach.

\section{Research Design}

The research design adopted for this study is Pre Experimental Research with One Group Pre-Test Post-Test Design

\section{Variables:-}

Independent variable:- In this study the independent variables are structured teaching programme and demographic variables.

Dependent variable: - In this study the dependent variables are knowledge about zika fever and its management.

\section{Population}

The population under study is those who admitted in medical ward at District Hospital, Durg.

\section{Accessible Population:-}

The accessible population in this study includes patients between the age group of 25 year to 45 years, admitted in District Hospital.

\section{Target Population:-}

The target population in this study includes 60 patients admitted in medical ward.

\section{Sample}

The present study was conducted among the patients who are admitted in medical ward at District Hospital Durg

\section{Sampling Technique}

A Convenient Non-probability Sampling

Technique was used to select the sample.

\section{Sample Size}

60 patients those who are admitted in medical ward during the study period.

Plan for Data Analysis: Data will analyse by using descriptive and inferential statistics.

Description of Tool; - A structured questionnaire will be developed as a tool for data collection. It will consist of the following section.

\section{Section A:-}

It includes the demographic data such as age, gender, religion, education, monthly income, area of living, type of family, drainage, food habits.

Section B: - Including 20 multiple choice questions related to zika fever and it's prevention. 
Scoring: - The questionnaire contains 20 each multiple choice questions. Each correct answer carries 1 mark and each wrong answer carries zero (0) mark.

\section{Grading of Marks:-}

\begin{tabular}{|c|l|l|l|}
\hline S.No & Score & Percentage & $\begin{array}{l}\text { Level of } \\
\text { Knowledge }\end{array}$ \\
\hline 1 & $01-10$ & $<50$ & $\begin{array}{l}\text { Inadequate } \\
\text { Knowledge }\end{array}$ \\
\hline 2 & $11-15$ & $50-75$ & $\begin{array}{l}\text { Moderately } \\
\text { Adequate } \\
\text { Knowledge }\end{array}$ \\
\hline 3 & $16-20$ & $>75$ & $\begin{array}{l}\text { Adequate } \\
\text { Knowledge }\end{array}$ \\
\hline
\end{tabular}

\section{RESULTS:}

Table:1 Level of Knowledge Regarding Zika Fever

\begin{tabular}{|l|c|c|}
\hline $\begin{array}{l}\text { Level of } \\
\text { Knowledge }\end{array}$ & Pre Test & Post Test \\
\hline $\begin{array}{l}\text { Inadequate } \\
\text { knowledge }\end{array}$ & $40(66.67 \%)$ & $12(20 \%)$ \\
\hline $\begin{array}{l}\text { Moderately } \\
\text { adequately } \\
\text { knowledge }\end{array}$ & $20(33.33 \%)$ & $42(70 \%)$ \\
\hline $\begin{array}{l}\text { Adequate } \\
\text { knowledge }\end{array}$ & $0(0 \%)$ & $6(10 \%)$ \\
\hline
\end{tabular}

In pre-test out of 60 samples 40 having inadequate knowledge, 20 having moderate knowledge and 0 member having adequate knowledge.

In post-test out of 60 samples 12 having inadequate knowledge, 42 having moderate knowledge and 6 member having adequate knowledge.

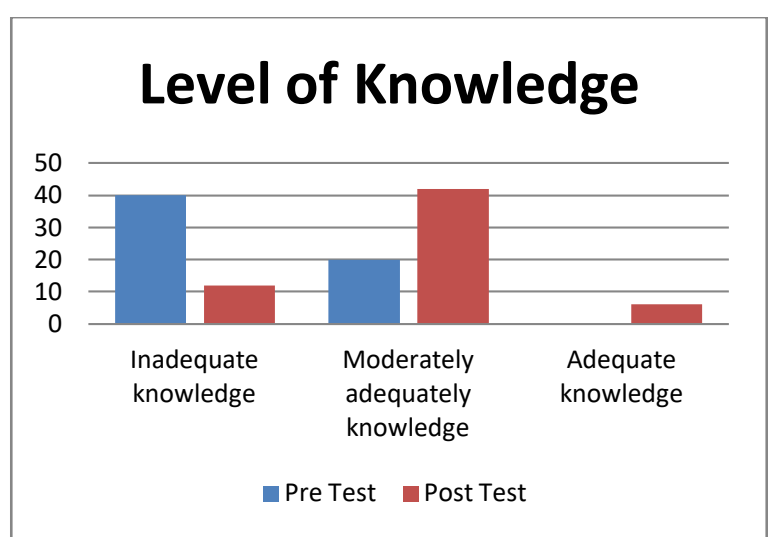

Figure 1 Comparison of distribution knowledge score in pre-test and post-test
Table: -2 Mean and Standard Deviation Value of Pre Test and Post-Test of Knowledge

\begin{tabular}{|l|c|c|}
\hline Description & Mean & Std Deviation \\
\hline Pre Test & 8.37 & 2.04 \\
\hline Post Test & 12.7 & 2.14 \\
\hline
\end{tabular}

Table:-2 shows that the mean and standard deviation value of knowledge in pre-test Mean 8.37, standard deviation 2.04 and in post test Mean 12.7, standard deviation 2.14.

\section{Effectiveness of Structure Teaching Programme on Knowledge Regarding Zika Fever}

The effectiveness of structure teaching programme on zika fever was assessed by paired $\mathrm{t}$ test. The value of $t$ is 10.4 at the level of $t=0.05$ level which is higher than the table value $t=2.05$ which show highly Significance. Hence H1 is accepted

\section{Association between Pre-Test Level of Knowledge and Demographic Variables}

The level of association between pre test knowledge and the Demographic variable of the sample where none of the Demographic variable such as age, gender, religion, education, family type, area of living, occupation, monthly income, drainage system, food habits are showing non- significance at $\mathrm{p}>0.05$.

\section{Implementation}

In this context, the health professionals, especially the nurse have a major role in providing information about zika fever and its management, which is one of the most cost effective weapons to reduce morbidity and mortality due to disease.

\section{Nursing Practice}

Nursing is an art and a science. As a science, nursing is based upon a knowledge that is always changing with new discoveries and innovations. When nurses integrate the science and art of nursing into their practice, the quality of care provided to clients is at a level of excellence that benefits clients in innumerable ways.

The finding of the present study emphasise the management and prevention of zika fever which can put into nursing practices in early identification of zika fever and a planned teaching programme can be used as a basis for educating them in prevention of this problem.

\section{Nursing Education}

Nursing may be defined 'as a dynamic, therapeutic and educative process in meeting health needs of the society.' The present study emphasises 
that health education on zika fever and its management is the key to prevent zika fever. In order to educate the patients and the community, it is essential that nurse are competent and have sound knowledge to improve the level of understanding on zika fever, improve the level of understanding which can be reflected to the public through education..

\section{Nursing Administration}

Health administration plays a vital role in supervision and management of nursing profession. The nurse administrators can utilise the present tool for assessing the knowledge of patients and implement some preventive measures based on the findings of the study. Teaching modules, group discussion and periodical educational sessions can also be arranged for the patients.

\section{Nursing Research}

Research is a systematic attempt to obtain meaningful answer to phenomena or events through the application of scientific procedures. It is an objective, impartial, empirical and logical analysis and recovering of controlled observations that may lead to the development of generalisations, principals of theories, resulting to some extent in prediction and control of events that may be the consequences or cause of specific phenomena.

The finding of the present study can be utilised by nurse researchers to contribute to the profession to accumulate new knowledge regarding zika fever and its management, can take professional accountability to educate and motivate the patients towards health promoting practices. The present study would helps nurses and other healthcare personnel to understand the level of knowledge of patients regarding management of zika fever.

The findings of the present study emphasise the management of zika fever which can be put into nursing practices in early identification of zika fever in patients and a structured teaching programme can be used as a basis for educating them in prevention of this problem.

\section{Bibliography-}

Books

1. Sr. Nancy. Fundamentals of nursing. $6^{\text {th }}$ ed. N.R. Brothers Publication; 2006. p. 347350.

2. Perry and Potter. Fundamentals of nursing practice. Noida $7^{\text {th }}$ ed.: Elsevier Publications; 2009 p. 797.

3. Basavanthappa BT. Fundamentals of nursing, New Delhi: Jaypee Brothers Publishers; 2002. p. 253-258.
4. TNAI Fundamentals of nursing procedure $1^{\text {st }}$ Ed published by secretary general on TNAI New Delhi 2005 p 226.

5. Gowda SN Nanjunde Foundation of nursing $1^{\text {st }}$ Ed published by Jaypee Brothers NewDelhi 2010 p 229.

\section{Net Reference}

1. Musso D, Gubler DJ. Zika Virus. Clinical Microbiology Rev 2016; 29:487.

2. Anderson KB, Thomas SJ, Endy TP. The Emergence of Zika Virus: A Narrative Review. Ann Intern Med 2016; 165:175.

3. Focosi D, Maggi F, Pistello M. Zika Virus: Implications for Public Health. Clinical Infectious Disease 2016; 63:227.

4. Tang H, Hammack C, Ogden SC, et al. Zika Virus Infects Human Cortical Neural Progenitors and Attenuates Their Growth. Cell Stem Cell 2016; 18:587.

5. Mlakar J, Korva M, Tul N, et al. Zika Virus Associated with Microcephaly. N England Journals Medicine 2016; 374:951.

6. Nowakowski TJ, Pollen AA, Di Lullo E, et al. Expression Analysis Highlights AXL as a Candidate Zika Virus Entry Receptor in Neural Stem Cells. Cell Stem Cell 2016; 18:591.

7. Sirohi D, Chen Z, Sun L, et al. The $3.8 \AA$ resolution cryo-EM structure of Zika virus. Science 2016; 352:467.

8. Garcez PP, Loiola EC, Madeiro da Costa R, et al. Zika virus impairs growth in human neurospheres and brain organoids. Science 2016; 352:816.

9. Fauci AS, Morens DM. Zika Virus in the Americas--Yet Another Arbovirus Threat. N Engl J Med 2016; 374:601.

10. Hennessey M, Fischer M, Staples JE. Zika Virus Spreads to New Areas - Region of the Americas, May 2015-January 2016. MMWR Morbidity Mortality Weekly Report 2016; 65:55.

11. Chen LH, Hamer DH. Zika Virus: Rapid Spread in the Western Hemisphere. Annual International Medicine 2016; 164:613.

12. World Health Organization. Emergencies: The history of Zika virus. http://www.who.int/emergencies/zikavirus/timeline/en/ (Accessed on February 25, 2016). 